\title{
"SELFIE" IN WEB DICTIONARIES
}

\author{
Seher ER \\ İstanbul Üniversitesi, Türkiye \\ erseher@istanbul.edu.tr \\ https://orcid.org/0000-0003-1411-3172
}

\begin{abstract}
The study includes Uludağ Dictionary, and ITU Dictionary, known as Web dictionaries. In the mentioned dictionaries, comments and attachments about the selfie lexicon unit (item/unit in the dictionary) or the word in everyday terms were examined in detail. Consequently, that the selfie lexicon/word was negatively evaluated.The review included in the study covers comments made in two dictionaries up to June 6,2014 . In the Uludağ dictionary and ITU dictionary search section of the article; the word "selfie" was entered. As a result, there were 281 comments were found about 'selfie' in the ITU dictionary. In the Uludağ dictionary, 205 comments were made about 'selfie'. The study revealed a difference in the interpretation of the selfie lexicon. Here, we aim to understand the text that contains the descriptions written in dictionaries. The comments in the Uludag dictionary were examined detail. In Istanbul technical University dictionary, only the direction of the comments was revealed.The word, which is defined as an individual selection and realization, is in a sense the production of another word. In the dictionary of linguistics terms, the definition of the dictionary is as follows. "Dictionary: It is a work that presents all or part of lexical units in a language with definitions, pronouncements, origins, uses, grammatical synonyms or their counterparts in another language, usually according to the order, and in some cases by subject or conceptual areas. Comments included in Web dictionaries were classified according to topics or conceptual areas in the context of this definition. The second classification of interpretations was made in the context of a predictor of status, descriptive, the explanatory relations between explanatory facts, a generalizing hypothesis tester. In the third classification of comments, emotion analysis was performed.
\end{abstract}

Keywords: Communication, Selfie, Web, Sentimental Analyses, İTÜ Dictionary, Uludă̆ Dictionary, Dictionary

\section{WEB SÖZLÜKLERDE “SELFIE” ÖZÇEKIM}

\section{ÖZ}

Çalışmada Web Sözlüğü olarak bilinen Uludağ Sözlüğü ile İTÜ Sözlüğü yer aldı. Anılan Sözlüklerde Selfie sözlükbirimi (sözlükte yer alan madde/birim) ya da gündelik anlamıla sözcügü//kelimesi konusunda yapılan yorumlar ve ekler ayrıntılı incelendi. Selfie sözlükbirimin/kelimesinin olumsuz değerlendirildiği saptandı. Çalışmada yer alan inceleme iki sözlükte 6 Haziran 2014 tarihine kadar yapılan yorumları kapsamaktadır. Uludağ sözlüğün ve İTÜ Sözlügün arama bölümüne Selfie maddesi girildi. Sonuçta İTÜ sözlükte Selfie'yle ilgili 281 yorum yapılmış olduğu görüldü. Uludağ sözlükte ise Selfie'yle ilgili 205 yorum yapıldığı saptandı. Çalışmada Selfie sözlükbiriminin yorumu, yorum farkı saptandı. Sözlüklerde yazılan açıklamaları içeren metni anlamak amacındayız. Uludağ sözlükte yer alan yorumlar ayrıntı incelendi. İTÜ. Sözlükte yer alan yorumların yalnızca yönü saptandı. Bireysel bir seçme ve gerçekleştirme edimi olarak nitelenen Söz bir anlamda sözce üretmedir. Dilbilim terimleri sözlüğünde sözlük tanımı şöyle yapılmaktadır. "Bir dildeki sözlüksel birimlerin tümünü ya da bir bölümünü, genellikle abecesel düzene, kimi durumlarda da konulara ya da kavramsal alanlara göre tanımları, tanıkları söylenişleri, kökenleri, kullanımları, dilbilgisi ulamları eşanlamlıları ya da bir başka

Research Article - This article was checked by iThenticate

Copyright (C) The Turkish Online Journal of Design, Art and Communication 
dildeki karşılıklarıyla sunan yapıt. Bu tanım bağlamında konular ya da kavramsal alanlara göre Web sözlüklerinde yer alan yorumlar sınıflandırıldı. Yorumların İkinci Sinıflandırması Durum Saptayıc1 Betimleyici, Açılayıcı Olgular arası ilişkiler, Genelleyici bir varsayım sınayıcı bağlamında yapıldı. Yorumların üçüncü sınıflandırmasında duygu analizi yapıldı.

Anahtar Kelimeler: İletişim,Web, Özçekim, Duygu Analizi, ITÜ Sözlüğü, Uludağ Sözlüğü, Sözlük

\section{INTRODUCTION}

The study includes Uludağ Dictionary, and ITU Dictionary, known as Web dictionaries. Such dictionaries do not contain purely encyclopedic information. People named as commentators in the dictionary convey up-to-date, subjective and speculative information about their own opinions. In the mentioned dictionaries, comments and attachments about the selfie lexicon unit (item/unit in the dictionary) or the word in everyday terms were examined in detail. Consequently, it was found that hundreds of comments were made on the Selfie lexicon in 2014 with a much more clear expression than in the year 2013 and that the selfie lexicon/word was negatively evaluated.

The founders of Uludağ dictionary, who are involved in the research, tell their stories on their Facebook pages as follows: it is an internet site that was opened in 2005. Since 2005, Uludağ Dictionary has become a reference source and has become the information repository of Turkey. Every day, hundreds of or thousands of readers read the information written by the authors of the Uludag dictionary and make use of the information.

On the other hand, ITU Dictionary included in the study is a dictionary formed by the students of Istanbul Technical University. Wikipedia, free encyclopedia is also described as an interactive dictionary with terms and descriptions added and updated by its members, and ITU Dictionary is described as a participatory dictionary.

\section{Purpose- Content- Method}

The review included in the study covers comments made in two dictionaries up to June 6, 2014. In the Uludağ dictionary and ITU dictionary search section of the article; the word "selfie" was entered . As a result, there were 281 comments were found about 'selfie' in the ITU dictionary. In the Uludag dictionary, 205 comments were made about 'selfie'. The study revealed a difference in the interpretation of the selfie lexicon. Here, we aim to understand the text that contains the descriptions written in dictionaries. The comments in the Uludağ dictionary were examined in detail. In Istanbul technical University dictionary, only the direction of the comments was revealed. The word, which is defined as an individual selection and realization, is in a sense the production of another word. In the dictionary of linguistics terms, the definition of the dictionary is as follows. "Dictionary: It is a work that presents all or part of lexical units in a language with definitions, pronouncements, origins, uses, grammatical synonyms or their counterparts in another language, usually according to the order, and in some cases by subject or conceptual areas." (Vardar, 1998: 191). Comments included in Web dictionaries were classified according to topics or conceptual areas in the context of this definition. The second classification of interpretations was made in the context of a predictor of status, descriptive, the explanatory relations between explanatory facts, a generalizing hypothesis tester. In the third classification of comments, emotion analysis was performed. Emotional Analysis: it aims to determine emotional expressions in texts. The most commonly used is sentimental polarity. According to this, it is aimed to divide the messages or articles about a subject into two classes according to whether they are positive or negative. However, emotion analysis also works on the determination of mood, contentment and more complex emotions in texts (http:sadievrenseker.com).

Research Article - This article was checked by iThenticate 


\section{Findings}

Susan Sontaq describes the picture as "a passion for capturing what's outside of us." People take pictures to make sure that they exist. A person also shares the picture he took to declare his presence. Lev Manovich and his team prepared theoretical studies on new media. (selfiecity.net): at this address the detail of the work is included. Selfie analysis has been conducted in 5 main cities around the world. The saturation point of the colors in this study is the tone and brightness levels, and the cultural meaning of the Selfie, etc have been identified. It is also possible to perform semiotic analysis of images.

This section contains the results obtained in the context of the classifications detailed in the purpose, content section. When the direction of the comments made on the selfie lexicography unit was determined, negative reviews were given in the first place in both dictionaries. Positive reviewers were ranked the second, and those who provided selfie-related information without any assessment were ranked the third. Evaluations were made as stacked method.

\section{Selfie Lexicography}

This section includes the results obtained in the context of the classifications described in the contents, purpose section. The direction of the comments made in the dictionary and the Uludag Dictionary was determined: negative, positive, under neutral definitions...

\section{Chart 1 İTÜ Dictionary}

$\begin{array}{lcc}\text { Direction } & \mathrm{n} & \% \\ \text { Negative } & 152 & 54.0 \\ \text { Positive } & 90 & 32.0 \\ \text { Impartial } & 39 & 13.0 \\ \text { Total } & 281 & 100.0\end{array}$

54 percent of 281 comments in ITU dictionary were found to be negative. Those who positively evaluated the selfie dictionary unit is: (32 percent). It was found that 13 percent of those who did not make any positive or negative comments about our dictionary unit in question were those who made explanations.

\section{Chart 2-Uludağ Dictionary}

$\begin{array}{lrc}\text { Direction } & \mathrm{n} & \% \\ \text { Negative } & 103 & 50.2 \\ \text { Positive } & 75 & 36.6 \\ \text { Impartial } & 27 & 13.2 \\ \text { Total } & 205 & 100.0\end{array}$

50.2 percent of 205 comments in the Uludağ dictionary were found to be negative. Those who positively evaluated the selfie dictionary unit is ( 36.6 percent). The ones who did not make any positive or negative comments about the selfie dictionary unit were the ones who made explanations and they were 13.2 percent.

\section{The Place of Selfie Dictionary Unit in Dictionary Definition}

The definition of the Selfie dictionary unit is given in (dictionary.com) as follows: "Photograph taken with the smart phone or another digital camera, especially to be published on the social media website." It is stated that celebrities do such sharing on Twitter. It is also possible to see celebration, political and ceremonial selfies on different websites. 
In this part of the study, Web dictionaries were examined in the context of the dictionary definition of Berke Vardar. The classifications are made from this definition: Definition, Reference, Usage, Grammar categories, Synonyms.

\section{Chart 3- Dictionary Definition}

$\begin{array}{lrc} & \mathrm{n} & \% \\ \text { Definition } & 25 & 11.4 \\ \text { Reference } & 7 & 3.2 \\ \text { Etymology } & 50 & 22.8 \\ \text { Usage } & 119 & 54.4 \\ \text { Synonyms } & 18 & 8.2 \\ \text { Total } & 219 & 100.0\end{array}$

Chart 3 includes classifications made in the context of the description contained within Berke Vardar's definition of "dictionary", which is included in the Dictionary of Explanatory Linguistics Terms. Those who commented on the selfie (54.4 percent) were seen to make statements using this lexicon. It was found that those who gave information about the origins of the selfie lexicon ( 22.8 percent), those who defined the selfie lexicon or gave the description (11.4 percent), those who stated the synonym ( 8.2 percent), and those who made a reference statement ( 3.2 percent). These results also show that the Selfie lexicon enters directly into life. The use of Selfie lexicon is more meaningful than its Turkish counterpart (özçekim).

\section{Scientific Aspect Of The Selfie Lexicon}

In this section, the scientific research objectives of the explanations made in the Web dictionaries were determined.

\section{Chart 4- Scientific Aspect}

Situation Identification and

Situation Description

Relationships Between

Explanatory Facts

Total

$\begin{array}{cc}\mathrm{n} & \% \\ 99 & 77.3 \\ & \\ 29 & 22.7 \\ 128 & 100.0\end{array}$

In A. Aziz's work of 'Research methods-techniques and Communication"' (Aziz, 1994: 28), the reesearch according to the purpose is classified under three titles: Situational, Descriptive Research, Explanatory Research, Generalizing, an Assumption -testing Research. Comments made to the selfie dictionary unit within the research were evaluated according to this classification. As a result, the comments made on the selfie dictionary unit (77.3 percent) were intended to reveal the relationship between expalatory facts if it is "sitaution identification and situation description" ( 22.7 percent).

\section{Selfie Lexicography's State Of Emotion-Thought Reflection}

\section{Chart 5-Opinions-Feeelings}

$\begin{array}{lcc} & \mathrm{n} & \% \\ \text { Feelings } & 12 & 6.5 \\ \text { Opinions } & 172 & 93.4 \\ \text { Total } & 184 & 100.0\end{array}$

As shown in Table 5, Another classification was used in the evaluation of the comments made on the Selfie lexicon in Web dictionaries other than the classifications made above. Emotional-intellectual classification. It was found that those who explained their thoughts for the lexicon unit (93.4 percent)

Research Article - This article was checked by iThenticate 
and those who made emotional statements (6.5 percent) were the majority of those who explained their thoughts.

\section{Time For Selfie Lexicography Comments}

This section of the study revealed the dates and times of comments on the selfie dictionary unit. The study, which included two years of commentary, revealed a percentage of those who commented between 2013 and 2014. It was later determined which slice of the day the comments were made.

\section{Chart 6. Hours}

$\begin{array}{lrc} & \mathrm{n} & \% \\ \text { Morning } & 20 & 9.7 \\ \text { Afternoon } & 52 & 25.12 \\ \text { Evening } & 82 & 39.6 \\ \text { Night } & 53 & 25.6 \\ \text { Total } & 207 & 100.0\end{array}$

Table 6 revealed what time of day the comments for the selfie dictionary were made. Evening commentators (39.6 percent), night commenters (25.6 percent) and lunchtime commenters (25.1 percent) were found. The proportion of morning commenters (9.7 percent).

\section{Chart 7. Date}

$\begin{array}{lrr} & \mathrm{n} & \% \\ 2013 & 13 & 6.3 \\ 2014 & 193 & 93.7 \\ \text { Total } & 206 & 100.0\end{array}$

In addition to Table 6, the historical process of comments on the Selfie lexicon was determined in Table 7. Comments (93.7 percent) were made in 2014. Comments in 2013 were (6.3 percent).

Web Address With Comments - Visual-Video Presentation

In addition to the comments about the selfie dictionary unit, the web addresses, images, videos, and recommended web addresses were included.

\section{Chart 8. Attachments to the Comments}

$\begin{array}{lcc} & \mathrm{n} & \% \\ \text { Web } & 19 & 82.6 \\ \text { Visual (Video) } & 4 & 17.4 \\ \text { Total } & 23 & 100.0\end{array}$

\section{Analysis Of The Words Used-Extreme Interpretations Of Selfie Comments}

According to the ITU dictionary analysis results, it is stated that the selfie is a type of photo (cited 146 times). Later reviews were made that it was the current( cited it 46 times) and in fashion( cited it 45 times).

According to the analysis of the Uludağ Dictionary, a current (28 times passing) is stated first, then the TDK finds the corresponding "selfie" (6 times cited) lexicon unit is stated. Third, "Selfie" (It is used 94 times).

As a result of these evaluations, interesting words, determinations and propositions about the selfie were also included. The sequence of these determinations according to the number of preferences is as follows: 


\section{Uludağ Dictionary}

Nasty fashion-Nonsense Fashion, mental disorder, self-shooting, action, event, teenager taking pictures, socialtrend, egoism, exhibitionism, headache, dullness, art, unnecessary work, new vocabulary, technological word, self-portrait, imitation, artistic discourse, best friend, nice photographs, a better method of taking photos in the mirror, the latest fashion madness, nonsense, exaggeration, post-modern intelligent version of aking photos, posing, shooting, lady, ridiculous work, our lives, the application, take a natural photo, egoism, painting, photography technique, press, and take a photo, stop, take it, come together and take a photo, photo selfşe, herd psychology, representative of popular culture, the latest indicator of modern man's stupidity, new fun, new fad, wannabe, revealing, wannabe, look and take a photo, language-infected dirt, trend, photo shoot, electra pop music, method of taking photos, self-take fashion, virus, image pollution.

\section{ITU Dictionary}

Popular name, nonsense, taking photographs of yourself, psychological illness /motion, popular photography, özcekim: a new word, a disgrace, the act of taking photo of yourself, in 2013 the word of fashion, new stupidity, the new internet phenomenon of silliness, Crap name of Cobol, it is clear that the world's most ridiculous action image, adolescent hobby, the sadist friend in the truck, people's extreme hobby, the best, global age disease, the explosion of the ego, crazy, annoying new term, social media, fashion, literature, history, vocabulary, the most sincere trend, wannabe, it's like a new event, self, Oscar ceremony trend, instant self, song, exaggeration, I think so I am, herd psychology, selfie, one-armed monster, fun thing, leisure, self, Trend, activity, social pose, take a photo and take it again, , statement visual, system perception, modern age narcissism- action, new generation, the visual state of narcissism, self love, swan like discourse, universality, self-attraction, a social human photo in modern society.

\section{RESULT}

Due to the detailed examination of the study titled "Selfie in Web dictionaries", comments, definitions and explanations in Uludağ Dictionary cause an anxiety and stress while reading the majority of the explanations. It is an effect caused by the negative evaluations.

The study found that the majority of comments made on the selfie lexicon were negative. I.T.Ü Dictionary (54 percent), Uludağ Dictionary (50.2 percent). 53.9 percent of commenters used the selfie lexicon in their comments. Selfie lexicography for the historical process of explaining (22.8 percent). 77.3 percent of the comments contained descriptive descriptions. 92.9 of them preferred to explain their thoughts more about selfie lexicography than emotional explanation. In ITÜ Dictionary, it is stated that the selfie is primarily a type of photo (cited 146 times). In the Uludağ Dictionary, the use of the word Selfie directly was preferred (used 94 times). Comments on the Selfie lexicon included interesting words, determinations, propositions.

The vast majority of comments made in the dictionary were made in 2014. (93,7). On the other hand, the evening hours (39.6 percent) have been favoured to comment. Various web addresses have been given to support thoughts when making comments. (82.6 percent). Visual-video usage (17.4 percent) was determined.

\section{KAYNAKÇA}

Aziz, A. (1994). Araştırma Yöntemleri-Teknikleri ve İletişim, Turhan Kitabevi,Ankara.

Güz, N. (2014). Görüşme: Görüşme konusu: hazırlanan metnin genel yapısı ve yanıtların sınıflandırılması konusunda görüşüldü

Rifat, M. (2013). Açılklamalı Göstergebilim Sözlüğü, İstanbul: Türkiye İş Bankası Yay.

Sontaq, S. (2008). Fotoğraf Üzerine, İstanbul: Agora Kitaplığı.

Research Article - This article was checked by iThenticate

Copyright $(\mathbb{C}$ The Turkish Online Journal of Design, Art and Communication 
The Turkish Online Journal of Design, Art and Communication - TOJDAC

ISSN: 2146-5193, October 2020 Volume 10 Issue 4, p.539-545

Vardar, B.(1998). Açıklamalı Dilbilim Terimleri Sözlüğü, İstanbul: ABC Kitabevi.

\section{INTERNET KAYNAKLARI}

İTÜ Sözlük, https://www.itusozluk.com/goster.php/selfie Erişim Tarihi: 6 Haziran 2014

Uludağ Sözlük, http://www.uludagsozluk.com/k/selfie/, Erişim Tarihi: 6 Haziran 2014

http://www.dictionary.com/browse/selfie?s=t Erişim: 29. Mayıs 2017

http://selfiecity.net/Erişim tarihi: 29 Mayıs 2017

http://bilgisayarkavramlari.sadievrenseker.com. Erişim Tarihi: /2014/06/15/metin-madenciligi-textmining/

https://www.facebook.com/pg/uludagsozluk/about/?ref=page_internal Erişim 30 Mayıs 2017

https://www.facebook.com/pg/eksisozluk/about/?ref=page_internal Erisim 30 Mayıs 2017

http://dictionnaire.sensagent.leparisien.fr/ $\% \mathrm{C} 4 \% \mathrm{~B} 0 \mathrm{~T} \% \mathrm{C} 3 \% 9 \mathrm{C} \% 20 \mathrm{~S} \% \mathrm{C} 3 \% \mathrm{~B} 6 \mathrm{zl} \% \mathrm{C} 3 \% \mathrm{BCk} / \mathrm{tr}$-tr/

Erişim Tarihi: 30.5.2017 